\title{
Implementing blended-problem based learning through Google classroom in biology learning
}

\author{
Vitta Yaumul Hikmawati a,1, and Yeni Suryaningsih a,2 \\ a Pendidikan Biologi, Universitas Majalengka, JI K.H Abdul Halim No.103 Majalengka, West Java 45418, Indonesia \\ ${ }_{1}$ vittayaumul12@gmail.com*; ${ }^{*}$ yenialrasyid@gmail.com \\ ${ }^{*}$ Corresponding author
}

\begin{tabular}{|c|c|}
\hline ARTICLE INFO & ABSTRACT \\
\hline $\begin{array}{l}\text { Article history } \\
\text { Selected paper from The } 5^{\text {th }} \text { National } \\
\text { Seminar on Biology, Education, and } \\
\text { Environmental (NS-BEE), Malang, East } \\
\text { Java-Indonesia, November 21, } 2019 \text {. } \\
\text { Peer-reviewed by NS-BEE Committee } \\
\text { and Editorial Board of JPBI (Jurnal } \\
\text { Pendidikan Biologi Indonesia) }\end{array}$ & $\begin{array}{l}\text { Information technology is determinant factor in creating learning environment among } \\
\text { the } 21 \text { st Century generation. This qualitative descriptive research aimed to obtain } \\
\text { theoretical views and empirical evidences of the blended-problem based learning (PBL) } \\
\text { application. The data were collected through non-test technique through observation. } \\
\text { The observations were made to analyze student activities in each step of the blended- } \\
\text { PBL. In addition, the observations were also constructed to get a view of students' off- } \\
\text { task behaviors during learning. The results of this study indicated that Google } \\
\text { Classroom-assisted blended-PBL was well implemented in Biology learning. The all } \\
\text { students actively participated in searching for information related to the topics covered } \\
\text { as well as exhibiting off-task behavior. Based on the findings in this study it can be } \\
\text { concluded that blended-PBL can be implemented as an alternative model for learning } \\
\text { Biology in the } 21 \text { st Century. }\end{array}$ \\
\hline $\begin{array}{l}\text { Keywords } \\
\text { Blended learning } \\
\text { Blended-PBL } \\
\text { Google Classroom } \\
\text { Problem-based learning }\end{array}$ & $\begin{array}{l}\text { Copyright } \odot \text { 2020, Hikmawati \& Suryaningsih } \\
\text { This is an open access article under the CC-BY-SA license }\end{array}$ \\
\hline \multicolumn{2}{|c|}{$\begin{array}{l}\text { How to cite: Hikmawati, V. Y. \& Suryaningsih, Y. (2020). Implementing blended-problem based learning through google } \\
\text { classroom in biology learning. JPBI (Jurnal Pendidikan Biologi Indonesia), 6(2), 217-224. doi: https://doi.org/10. } \\
\text { 22219/jpbi.v6i2.12112 }\end{array}$} \\
\hline
\end{tabular}

\section{INTRODUCTION}

The world has changed dynamically and it has a real impact on the fulfillment of human needs (Çalışkan, 2015). In today's digital era, most human needs are met by online systems, including in the education field (Aysan, 2015). The development of science and information technology in the $21^{\text {st }}$ century can be viewed from two perspectives, as a challenge (Muresan \& Gogu, 2013) and also as a new opportunity for the education system (Rodrigues, Almeida, Figueiredo, \& Lopes, 2019). As a challenge, because teachers must be technology literate (Muresan \& Gogu, 2013; Tîrziu \& Vrabie, 2015). However, if viewed as an opportunity, students' cellular technology has the potential to be used as a tool to build a flexible learning environment without being bound by learning space and time (Mashhadia \& Kargozar, 2011; Rodrigues et al., 2019).

Collaboration between face-to-face learning and online learning is one of the strategic opportunities that can be exploited in this current information-based era. The large potential of information technology has led to relatively new strategies related to learning, such as the blended learning strategy. Blended learning is an important change in the learning environment of teachers and students (Dogan, 2017). In blended learning, teachers combine two different learning experiences, traditional face-to-face learning and distance learning 
(Kazu \& Demirkol, 2014). The combination of two learning experiences is intended to combine the positive aspects of the two learning conditions in order to achieve the expected target. Blended learning has at least three components consisting of teachers as mentors, online learning materials, and skills developed from learning experiences during classroom learning (Yapici \& Akbayin, 2012).

Theoretically, blended learning combines several beneficial aspects of online learning and face-to-face learning (Kazu \& Demirkol, 2014). On the other hand, blended learning requires a learning model that ensures effectiveness in online learning environments (Delialioğlu, 2012). The advantage of online learning is easy access to search for information (Apuke \& Iyendo, 2018; Luaran, Samsuri, Nadzri, \& Rom, 2014). The advantages of face-to-face learning are the interaction between teachers and students and students and students. The implementation of online learning needs to be supported by compatible applications to facilitate student learning experiences to be more varied and in-depth. Online applications used in the learning system have been developed to support the success of the learning system. One application that facilitates online learning by creating classrooms in cyberspace is Google Classroom. The Google Classroom application provides a powerful feature set that makes it the ideal tool for improving communication with students. The Google Classroom application can be accessed by students either via personal cellular or personal computers (PCs). Through Google Classroom, teachers have the freedom to share scientific studies and provide independent assignments to students and to open discussion spaces for students online (Asnawi, 2018). This application is available to everyone with Google Apps for Education, a suite of free productivity tools including Gmail, Drive and Docs.

Blended learning generally combines formal classroom learning methods such as Problem-based Learning (PBL) (Bregger, 2017; Shimizu, Nakazawa, Sato, Wolfhagen, \& Könings, 2019) or Project-based Learning (PjBL) (Klentien \& Wannasawade, 2016; Rahardjanto, Husamah, \& Fauzi, 2019) with e-learning. The collaboration between Blended Learning and the PBL model has a theoretical foundation. As a model, PBL has long been reported to have advantages, especially in changing the old paradigm of learning focus (Yew \& Goh, 2016). In the old paradigm, the learning process focused on passive absorption of information, while through PBL the focus of learning based on information seeking was carried out by students actively as emphasized in a constructivist perspective (Leibiger, 2011). The success of the teacher in implementing Blended-PBL as a student-centered learning model is dependent on student activities during learning. Through PBL, students will take part in a series of learning activities that emphasize the problem-solving process (Simamora, Sidabutar, \& Edy, 2017). By solving biological problems through PBL, students are directed to develop their abilities in building new knowledge, applying various strategies according to problem-solving needs.

Various student activities during the implementation of PBL are finding information, reading, selecting and evaluating various sources of information, assessing the opinions of others from different perspectives, finding solutions to problems (Mustaffa \& Ismail, 2015; Walker \& Leary, 2009). In learning activities, student learning activities are very important factors for the teacher to note (Simamora et al., 2017). Student activities that are not relevant to a series of learning activities are called off-task behaviors. Although there have been several previous studies that have examined PBL implementation, research that examines the factors associated with off-task behavior is very limited (Godwin, Almeda, Petroccia, \& Org, 2013). Research that examines the application of blended-PBL is also still focused on critical thinking skills (Anugraheni, 2018; Zabit, 2010), creative thinking (Birgili, 2015; Ersoy \& Baser, 2014), or metacognition (Kevin, 2011). Most of the various studies have not clearly stated what platforms are involved in online learning activities. Therefore, the purpose of this study is to examine the implementation of blended-PBL using Google Classroom and to examine the students' off-task behavior. This research is urgent to do because it will further encourage the implementation of blended learning in Indonesia, considering that the world of education is encouraged to digitize education. In addition, this study will clearly provide an overview of the role of free online learning platforms in optimizing the implementation of blended-PBL. Measuring off-task behavior will also provide basic information on learning variables that are still rarely studied in Indonesia.

\section{METHOD}

This study recorded student activity patterns and student off-task behavior during learning about cells through blended-PBL. The achievement of research objectives was carried out through a survey method with a qualitative descriptive approach. This research was conducted from July to August 2019 in the odd semester of the 2019/2020 school year. The subjects that were the focus of this study were all class XI IPA students of SMA Negeri 1 Majalengka in the 2019/2020 school year. The number of samples used was 36 students consisting of 22 female students and 14 male students. 
The implementation of blended-PB: was carried out in class XI of SMAN 1 Majalengka through a combination of online learning with classical face-to-face meetings. Online learning makes use of the Google Classroom application with various features that support investigative activities. In face-to-face meetings, it was carried out through group discussions to determine solutions. In online learning the teacher presents cellrelated problems through the "material" feature in Google Classroom. The teacher provides the opportunity for students to read and understand the discourse for 15 minutes. After 15 minutes have passed, the teacher use the "assignment" feature to send questions related to the material contained in the discourse.

The research data were collected through non-test techniques in the form of incident observation. Observations were made to analyze student activities at each blended-PBL step and to get an overview of students' off-task behavior during learning. Student learning activities during the implementation of the blendedPBL were recorded in the form of recording events or observation formats observed by three observers. The instrument used to record the incident was an observation sheet.

The data analysis technique was done descriptively. The appearance of each student's off-task behavior was recorded during the implementation of learning, then categorized and then percentage. The categorization of off-task behavior recorded during the application of blended-PBL refers to Godwin et al. (2013) with adjustments according to the observed pattern of events.

\section{RESULTS AND DISCUSSION}

In this study, when the teacher implements blended-PBL, the teacher asks several questions related to learning topics. The questions sent consist of "what do you know about the problems contained in the discourse?" what do you need to know about the problem? How are you going to do to find out more about the problem? What strategies will you use to solve the problem? These questions are intended to direct the information-seeking process and help students control their understanding of the issues being discussed.

As can be seen in Table 1, the results of observations of student activities during blended-PBL learning show that most students have carried out the blended-PBL steps. As a learning model, PBL has a syntax that facilitates students collaborating in small groups to solve real and complex problems (Loyens, Jones, Mikkers, \& van Gog, 2015; Wijnia, 2016). Thus, the success of Blended-PBL is influenced by the quality of collaboration between students during the investigation process to determine the solution to the problem. However, each step has not been completely carried out perfectly. The percentage of students who are not involved in learning activities according to PBL syntax is relatively small.

Based on the results, the blended-PBL syntax achievement is classified as low in the third step (carrying out group investigations). The low achievement of students in carrying out group investigations is because each member of the group works individually. Each member of the group tends to work independently and only focuses on doing the tasks assigned to him, without involving himself in the tasks of his group friends. The results of observations of student activities show that the work patterns of each group are relatively the same, namely starting with the division of tasks to each member of the group to find answers to the questions on the worksheet. Furthermore, the working stage was carried out in accordance with the tasks assigned. The last is collecting information from one of the students whose task is to collect answers from all members. There was no information collaboration and activity to review the results of information searches and the stage of determining solutions. The series of group investigation activities on PBL syntax became fragmented by the division of tasks that were not accompanied by collaboration and without reflection.

The results of this study also revealed that the participation of group members during the investigation of cell problems was not evenly distributed between one student and another. Students who are active tend to have a larger portion of work than students who are passive. The difference in the work portion of group members becomes one of the triggers for delays in the discussion process, and can even lead to conflicts among members which have an impact on the efficiency of the discussion process. Efficiency relates to the use of time in completing a series of investigative processes. Google Classroom actually records the time it takes students to answer each question asked. Judging from the time of collecting answers, it is known that students actively search for information related to problems presented by the teacher. The active participation of $94 \%$ of students in conducting searches can be traced from the link to articles collected by students through the assignment feature in Google Classroom. By opening the assignments collected by each student, the teacher can also assess the effectiveness of information sources based on their relevance to the problem and consider their efficiency in terms of the time of collection.

The data presented in Table 2 shows the average time it takes students to carry out each step in the blended-PBL. As Table 2 informs that the average time used to complete all stages in the blended-PBL syntax series is 6489 seconds or about 108.15 minutes while one face-to-face meeting for Science subjects is $2 \times 45$ 
minutes or 90 minutes. Blended-PBL allows the use of time longer than the predetermined time allocation, this can occur because some steps of the activity are carried out online outside of learning hours in the classroom. The step of identifying the problem is the first step of blended-PBL that students take online and independently.

Table 1. Description of student activities during blended-PBL implementation

\begin{tabular}{|c|c|c|}
\hline No & Syntax & Observed activity \\
\hline 1 & \multicolumn{2}{|c|}{ Stage I: Identify the Problem (Online Learning) } \\
\hline a & $\begin{array}{l}\text { Formulate problems in } \\
\text { the form of questions }\end{array}$ & $\begin{array}{l}79 \% \text { of students formulate questions according to the number set (minimum } 5 \text { items). } 44 \% \text { of the } \\
\text { questions made by students cannot be categorized as questions because they do not contain a } \\
\text { question word and or do not end with a question mark. } 48 \% \text { of students made complete and } \\
\text { relevant questions. } 8 \% \text { of students make questions that are not relevant to the problem. } 11 \% \text { of } \\
\text { students formulated questions less than } 5 \text {. }\end{array}$ \\
\hline $\mathrm{b}$ & Develop a hypothesis & $\begin{array}{l}82 \% \text { of students formulate hypotheses that are relevant to the problem. } 12 \% \text { of students formulated } \\
\text { a hypothesis that is not relevant and } 6 \% \text { did not make a hypothesis }\end{array}$ \\
\hline c & $\begin{array}{l}\text { Looking for information } \\
\text { relevant to the topic } \\
\text { discussed }\end{array}$ & $\begin{array}{l}94 \% \text { of students are looking for information relevant to the problem topic. only } 6 \% \text { of students did } \\
\text { not include the reference source link obtained, so it was difficult to measure the relevance of the } \\
\text { information they were looking for. }\end{array}$ \\
\hline 2 & \multicolumn{2}{|c|}{ Stage II: Organizing students to learn (Face to face meeting) } \\
\hline a & $\begin{array}{l}\text { Answer questions on } \\
\text { the worksheet }\end{array}$ & $\begin{array}{l}100 \% \text { of students answered the questions contained in the worksheets, although not all questions } \\
\text { were successfully answered because of limited time and limited capacity of students to answer }\end{array}$ \\
\hline $\mathrm{b}$ & $\begin{array}{l}\text { Determine the source } \\
\text { of information }\end{array}$ & $\begin{array}{l}82 \% \text { of students decided which reference sources they would use in their investigation, among } \\
\text { students who included reference sources only } 14 \% \text { used books as their reference sources, while } \\
86 \% \text { preferred digital articles and blogs as reference sources }\end{array}$ \\
\hline c & $\begin{array}{l}\text { Actively convey ideas } \\
\text { related to problems }\end{array}$ & $\begin{array}{l}26 \% \text { of students were able to express opinions related to cells, } 56 \% \text { of students were passive, and } \\
18 \% \text { did not participate }\end{array}$ \\
\hline 3 & \multicolumn{2}{|c|}{ Stage III: Guiding Group Investigations } \\
\hline a & $\begin{array}{l}\text { Collaborate to collect } \\
\text { data during the } \\
\text { investigation process }\end{array}$ & $\begin{array}{l}83 \% \text { of groups share tasks with their group friends. } 10-15 \text { minutes before the discussion time is } \\
\text { over, each group member gives the answer to their search result to one of the students who is in } \\
\text { charge of writing the answer. In this step, there was no information collaboration process or a joint } \\
\text { review of the search results carried out individually by each group member. Students tend to work } \\
\text { together on assignments rather than collaborating and sharing ideas or information. }\end{array}$ \\
\hline $\mathrm{b}$ & $\begin{array}{l}\text { Selecting information } \\
\text { from the collected data }\end{array}$ & $\begin{array}{l}\text { Each member of the group carries out the information selection process by considering the } \\
\text { relevance and accuracy, but most students tend to ignore the credibility of the information they get. }\end{array}$ \\
\hline c & $\begin{array}{l}\text { Discuss solutions } \\
\text { based on selected } \\
\text { information }\end{array}$ & $\begin{array}{l}\text { This activity was only carried out by a small part of the group, most of the others did not do this } \\
\text { activity. }\end{array}$ \\
\hline 4 & \multicolumn{2}{|c|}{ Stage IV: Develop and present the work } \\
\hline a & $\begin{array}{l}\text { Collaborate to design } \\
\text { products }\end{array}$ & $\begin{array}{l}\text { Each group member collaborates to design a product; } 30 \% \text { of groups designed paper-based } \\
\text { posters, } 70 \% \text { of groups agreed to make designs in the form of digital-based posters. }\end{array}$ \\
\hline $\mathrm{b}$ & $\begin{array}{l}\text { Present the product } \\
\text { design }\end{array}$ & $\begin{array}{l}\text { Each group enthusiastically presented their poster designs. The group that presented their designs } \\
\text { was dominated by one to two people, while the other group members tended to be passive. }\end{array}$ \\
\hline$c$ & $\begin{array}{l}\text { Consider suggestions } \\
\text { from teachers and other } \\
\text { groups for product } \\
\text { development }\end{array}$ & $\begin{array}{l}\text { Another group responded and gave suggestions on a poster design presented by a friend. This } \\
\text { process was quite interactive and took a relatively long time due to the large number of comments } \\
\text { and inputs from other groups. }\end{array}$ \\
\hline 5 & \multicolumn{2}{|c|}{ Stage V: Analyze and evaluate the problem-solving process } \\
\hline a & $\begin{array}{l}\text { Evaluate the stages of } \\
\text { the problem-solving } \\
\text { process }\end{array}$ & $\begin{array}{l}\text { At this stage the students and their groups evaluate and review the problem-solving process they } \\
\text { have done. Not all group members participated in this step, only } 1-2 \text { students were actively } \\
\text { involved in doing this step. }\end{array}$ \\
\hline $\mathrm{b}$ & $\begin{array}{l}\text { Create alternative } \\
\text { solutions }\end{array}$ & $\begin{array}{l}\text { Students and their groups make alternative solutions as suggested by the teacher and other } \\
\text { groups. }\end{array}$ \\
\hline c & $\begin{array}{l}\text { Formulate the right } \\
\text { conclusions }\end{array}$ & $\begin{array}{l}\text { Each group discusses the conclusions of the problem-solving process that has been carried out. } \\
\text { On average, in each group this activity is dominated by } 1-2 \text { people, while other group members } \\
\text { tend to be passive without contributing ideas. }\end{array}$ \\
\hline
\end{tabular}

Table 2. Time required for each Blended-PBL stage

\begin{tabular}{lc}
\hline \multicolumn{1}{c}{ Blended-PBL syntax } & Average time taken (seconds) \\
\hline Identify the problem (online learning) & 1084 \\
Organize student to learn & 1567 \\
Conduct group investigations & 1968 \\
Develop and present the work & 1088 \\
Analyze and evaluate the problem solving process & 782 \\
\hline \multicolumn{2}{c}{ Total }
\end{tabular}


The problem of cell dysfunction presented by the teacher at the beginning of the lesson encourages students to find out and collect information related to the problem. By collecting information related to the problems discussed, students involve their memories, ideas, interests and experiences to reflect on the chosen topic and make connections between the information they have obtained.

The time required for each group to carry out an investigation varies greatly from group to group. The average time that is most widely used is to complete the stage of carrying out a group investigation, 1968 seconds or about 32 minutes. The better the quality of cooperation among group members, the faster the time it takes for the group to carry out investigations. The quality of student cooperation in a group is highly dependent on the work ethic of students and their individual approach as group members (Saliba, Mussleman, Fernandes, \& Bendriss, 2017). Differences in perspective, communication and work rhythm are the main obstacles that occur in several groups. Conflict between students is almost not found in groups whose members have personal closeness, thus it does not take much time for the discussion process. This finding is consistent with the previous results which reported that substantial differences in intelligence, expectations and work styles can create conflicts among students while working in groups (Olivo, 2012).

Furthermore, the results of recording events carried out by observers in this study indicated that during the application of blended-PBL most students (78\%) showed on-task behavior. As many as $22 \%$ of students still showed off-task behavior with details of the types of off-task as can be seen in Figure 1. There were five types of off-task behavior shown by students during the application of blended-PBL. The five types of off-task behavior that arise are: 1) self-distraction, 2) peer distraction, 3) supplies, 4) environmental distraction and 5) others. Nearly half of the students who show off-task behavior (49\%) show supply distraction. The categories of supply distractions that arise during blended-PBL learning are students using their cell phones for purposes other than assignments given by the teacher such as replying to personal messages, searching for information that is not related to the topic of discussion, opening social networks. As many as $18 \%$ of the total students who showed off-task behavior during the blended-PBL learning were included in the peer-destructions category. The results of the observations indicated that the emergence of interference from peers occurred in group investigation activities. The self-destruction behavior observed from $14 \%$ of students was that students' attention was diverted to the attributes of their clothes, this behavior all appeared in female students. Environmental destructions were shown by $8 \%$ of students whose attention was diverted to activities outside the classroom. Other disorders (other destructions) indicated by $11 \%$ of students, observed behavior is difficult to categorize because it does not fit with other categories. The behavior that appeared was like leaving the classroom.

The results of this study also reveal that the application of PBL shows a positive impact on the learning process. The findings of this study are in line with previous research (Triyanto, Susilo, \& Rohman, 2016) which states that blended-PBL provides an environment that supports students to do positive activities. Positive activity indicators shown by students can be seen from the high involvement of students in learning and the average time needed to complete each stage in the blended-PBL. The actual use of cellular technology can be used as a tool to find information in blended-PBL learning assisted by Google classroom. The low percentage of students who show off-task behavior due to personal cell phone use. The findings reinforce PBL's position as innovative learning which has been reported to be able to optimize learning processes (Dring, 2019; Movahedzadeh, Patwell, Rieker, \& Gonzalez, 2012; Yew \& Goh, 2016) and outcomes (Mundilarto \& Ismoyo, 2012; Zejnilagić-Hajrić, Šabeta, \& Nuić, 2015). The combination of PBL with online learning in this study is also in line with previous research which also informs about an increase in science learning when blended-PBL is implemented in learning (Ammann, Vignoli, \& Kaap-Fröhlich, 2019; Car et al., 2019).

In connection with the informed findings, Blended-PBL is expected to be an alternative for teachers to reduce the percentage of off-task behavior. As is well known, off-task behavior is one of the main problems that needs serious attention (Godwin et al., 2013). The high level of off-task behavior has the potential to reduce the quality of learning (Beserra, Nussbaum, \& Oteo, 2019) and students' achievement (Moffett \& Morrison, 2020). Therefore, the teacher needs to evaluate off-task and on-task behavior to reflect on the learning process.

The use of certain learning management systems can facilitate teachers to observe and evaluate the duration of students' on-task behavior (Kovanovic et al., 2015). However, the application of distance learning has the potential to increase the percentage of off-task behavior (Terzi \& Çelik, 2005). On the other hand, in the current digitalization era, learning is expected to be able to continuously involve various educational technologies, including online learning technology (Puspitasari, Surjono, \& Minghat, 2018; Valverde-Berrocoso, Garrido-Arroyo, Burgos-Videla, \& Morales-Cevallos, 2020). The high on-task behavior when e-learning learning is combined with PBL in this study is an interesting finding because it further strengthens the power of PBL as an innovative 21st century learning. In addition, learning activities in PBL syntax can increase student engagement (Tarmizi, Tarmizi, Lojinin, \& Mokhtar, 2010). Learning activities that encourage students to solve 
contextual problems can also increase student motivation (Thakur \& Dutt, 2017). These conditions can affect the percentage of students' on-task behavior.

\section{CONCLUSION}

The implementation of blended-PBL in cell material is well implemented through the use of cellular technology as a tool for finding information. During the blended-PBL application, most of the students showed behaviors related to information-seeking tasks. Research that examines both blended-PBL and off-task behavior is recommended to be expanded. Research that examines the implementation of blended-PBL is one way to disseminate and socialize this learning innovation to various schools in Indonesia. In addition, blendedPBL can also be an alternative solution in optimizing the digitalization of education. In future studies, research with other approaches also needs to be done, especially a quantitative approach. By implementing the experimental design, researchers will be able to study the effect of blended-PBL on off-task behavior when compared to face-to-face PBL learning or full online PBL learning.

\section{REFERENCES}

Ammann, D., Vignoli, Y., \& Kaap-Fröhlich, S. (2019). How can problem-based learning be realised in blended learning format? Contribution to the HoGe conference 2018 "Digital learning and teaching". International Journal of Health Professions, 6(1), 90-96. doi: https://doi.org/10.2478/ijhp-2019-0010

Anugraheni, I. (2018). A meta-analysis of problem-bas ed learning models in Increasing critical thinking skills in elementary schools. Polyglot: Jurnal IImiah, 14(1), 9-18. doi: https://doi.org/10.19166/pji.v14i1.789

Apuke, O. D., \& lyendo, T. O. (2018). University students' usage of the internet resources for research and learning: forms of access and perceptions of utility. Heliyon, 4(12), e01052. doi: https://doi.org/10.1016/ j.heliyon.2018.e01052

Asnawi, N. (2018). Pengukuran usability aplikasi google classroom sebagai E-learning menggunakan USE questionnaire (studi kasus: Prodi Sistem Informasi UNIPMA). Research : Computer, Information System \& Technology Management, 1(1), 17-21. doi: https://doi.org/10.25273/research.v1i1.2451

Aysan, E. (2015). Learning science and science education in a new era. Annals of Medicine and Surgery, 4(2), 158-161. doi: https://doi.org/10.1016/j.amsu.2015.04.026

Beserra, V., Nussbaum, M., \& Oteo, M. (2019). On-task and off-task behavior in the classroom: A study on mathematics learning With educational video games. Journal of Educational Computing Research, 56(8), 1361-1383. doi: https://doi.org/10.1177/0735633117744346

Birgili, B. (2015). Creative and critical thinking skills in problem-based learning environments. Journal of Gifted Education and Creativity, 2(2), 71-80. doi: https://doi.org/10.18200/JGEDC.2015214253

Bregger, Y. A. (2017). Integrating blended and problem-based learning into an architectural housing design studio: A case study. Journal of Problem Based Learning in Higher Education, 5(1), 126-137. doi: https://doi.org/10.5278/ojs.jpblhe.v0i0.1553

Çalışkan, H. K. (2015). Technological change and economic growth. In Procedia - Social and Behavioral Sciences (Vol. 195, pp. 649-654). doi: https://doi.org/10.1016/j.sbspro.2015.06.174

Car, L. T., Kyaw, B. M., Dunleavy, G., Smart, N. A., Semwal, M., Rotgans, J. I., ... Campbell, J. (2019). Digital problem-based learning in health professions: Systematic review and meta-analysis by the digital health education collaboration. Journal of Medical Internet Research, 21(2), 1-12. doi: https://doi.org/10.2196/ 12945

Delialioğlu, Ö. (2012). Student engagement in blended learning environments with lecture-based and problem-based instructional approaches. Educational Technology and Society, 15(3), 310-322. Retrieved from http://citeseerx.ist.psu.edu/viewdoc/download?doi=10.1.1.298.8303\&rep=rep1\&type=pdf

Dogan, N. (2017). Blending problem based learning and history of science approaches to enhance views about scientific inquiry: New wine in an old bottle. Journal of Education and Training Studies, 5(10), 99112. doi: https://doi.org/10.11114/jets.v5i10.2646

Dring, J. C. (2019). Problem-based learning - Experiencing and understanding the prominence during medical school: Perspective. Annals of Medicine and Surgery, 47, 27-28. doi: https://doi.org/10.1016/j. amsu.2019.09.004

Ersoy, E., \& Baser, N. e. (2014). The effects of problem-based learning method in higher education on 
creative thinking. Procedia - Social and Behavioral Sciences, 116, 3494-3498. doi: https://doi.org/10. 1016/j.sbspro.2014.01.790

Godwin, K., Almeda, V., Petroccia, M., \& Org, E. (2013). Classroom activities and off-task behavior in elementary school children. In Proceedings of the Annual Meeting of the Cognitive Science Society (pp. 2428-2433). Retrieved from https://cloudfront.escholarship.org/dist/prd/content/qt8mx9h5hq/qt8mx9h5 hq.pdf

Kazu, I. Y., \& Demirkol, M. (2014). Effect of blended learning environment model on high school students' academic achievement. Turkish Online Journal of Educational Technology - TOJET, 13(1), 78-87. Retrieved from http://search.ebscohost.com/login.aspx?direct=true\&db=eric\&AN=EJ1018177\&site=eho st-live

Kevin, D. (2011). Impact of problem-based learning on student experience and metacognitive development. Multicultural Education \&amp; Technology Journal, 5(1), 55-69. doi: https://doi.org/10.1108/17504971 111121928

Klentien, U., \& Wannasawade, W. (2016). Development of blended learning model with virtual science laboratory for secondary students. In Procedia - Social and Behavioral Sciences (Vol. 217, pp. 706711). doi: https://doi.org/10.1016/j.sbspro.2016.02.126

Kovanović, V., Gasević, D., Dawson, S., Joksimović, S., Baker, R. S., \& Hatala, M. (2015). Does time-on-task estimation matter? Implications for the validity of learning analytics findings. Journal of Learning Analytics, 2(3), 81-110. doi: https://doi.org/10.18608/jla.2015.23.6

Leibiger, C. A. (2011). "Google reigns triumphant"?: Stemming the tide of googlitis via collaborative, situated information literacy instruction. Behavioral \& Social Sciences Librarian, 30(4), 187-222. doi: https://doi. org/10.1080/01639269.2011.628886

Loyens, S. M. M., Jones, S. H., Mikkers, J., \& van Gog, T. (2015). Problem-based learning as a facilitator of conceptual change. Learning and Instruction, 38, 34-42. doi: https://doi.org/10.1016/j.learninstruc.2015. 03.002

Luaran, J. E., Samsuri, N. N., Nadzri, F. A., \& Rom, K. B. M. (2014). A study on the student's perspective on the effectiveness of using e-learning. In Procedia - Social and Behavioral Sciences (Vol. 123, pp. 139144). doi: https://doi.org/10.1016/j.sbspro.2014.01.1407

Mashhadia, V. Z., \& Kargozar, M. R. (2011). Influences of digital classrooms on education. In Procedia Computer Science (Vol. 3, pp. 1178-1183). doi: https://doi.org/10.1016/j.procs.2010.12.190

Moffett, L., \& Morrison, F. J. (2020). Off-task behavior in kindergarten: Relations to executive function and academic achievement. Journal of Educational Psychology, 112(5), 938-955. doi: https://doi.org/10. 1037/edu0000397

Movahedzadeh, F., Patwell, R., Rieker, J. E., \& Gonzalez, T. (2012). Project-based learning to promote effective learning in biotechnology courses. Education Research International, 2012, 1-8. doi: https:/l doi.org/10.1155/2012/536024

Mundilarto, M. \& Ismoyo, H. (2012). Effect of problem-based learning on Improvement physics achievement and critical thinking of senior high school student. Journal of Baltic Science Education, 16(0), 761-779. Retrieved from http://www.scientiasocialis.It/jbse/?q=node/609

Muresan, M., \& Gogu, E. (2013). E-learning challenges and provisions. In Procedia - Social and Behavioral Sciences (Vol. 92, pp. 600-605). doi: https://doi.org/10.1016/j.sbspro.2013.08.724

Mustaffa, N., \& Ismail, Z. (2015). Problem-Based Learning (PBL) in schools: A meta-analysis. In 12th International Conference of The Mathematics Education into the 21st Century Project The Future of Mathematics Education in a Connected World. Herceg Novi. Retrieved from https://www.research gate.net/publication/280734423\%0AProblem-Based

Olivo, R. F. (2012). Collaborative online writing assignments to foster active learning. Journal of Undergraduate Neuroscience Education, 11(1), 82-89. Retrieved from https://www.ncbi.nlm.nih.gov /pmc/articles/PMC3592738/pdf/june-11-82.pdf

Puspitasari, E. D. T., Surjono, H. D., \& Minghat, A. D. (2018). Utilizing web based learning as 21 st century learning media for vocational education. International Journal of Engineering and Technology(UAE), 7(4), 157-160. doi: https://doi.org/10.14419/ijet.v7i4.33.23522

Rahardjanto, A., Husamah, H., \& Fauzi, A. (2019). Hybrid-PjBL: Learning outcomes, creative thinking skills, and learning motivation of preservice teacher. International Journal of Instruction, 12(2), 179-192. doi: https://doi.org/10.29333/iji.2019.12212a

Rodrigues, H., Almeida, F., Figueiredo, V., \& Lopes, S. L. (2019). Tracking e-learning through published 
papers: A systematic review. Computers \& Education, 136, 87-98. doi: https://doi.org/10.1016/j.com pedu.2019.03.007

Saliba, R., Mussleman, P., Fernandes, M., \& Bendriss, R. (2017). Promoting information literacy of premedical students through project-based ;earning: A pilot study. International Journal of Education and Literacy Studies, 5(4), 1-15. doi: https://doi.org/10.7575/aiac.ijels.v.5n.4p.1

Shimizu, I., Nakazawa, H., Sato, Y., Wolfhagen, I. H. A. P., \& Könings, K. D. (2019). Does blended problembased learning make Asian medical students active learners?: A prospective comparative study. BMC Medical Education, 19(147), 1-9. doi: https://doi.org/10.1186/s12909-019-1575-1

Simamora, R. E., Sidabutar, D. R., \& Edy, S. (2017). Improving learning activity and students' problem solving skill through problem based learning (PBL) in junior high school. International Journal of Sciences: Basic and Applied Research (IJSBAR), 33(2), 321-331. Retrieved from http://gssrr.org/index.php?jou rnal=JournalOfBasicAndApplied

Tarmizi, R. A., Tarmizi, M. A. A., Lojinin, N. I., \& Mokhtar, M. Z. (2010). Problem-based learning: Engaging students in acquisition of mathematical competency. In Procedia - Social and Behavioral Sciences (Vol. 2, pp. 4683-4688). doi: https://doi.org/10.1016/j.sbspro.2010.03.750

Terzi, S., \& Çelik, A. (2005). Teacher-student interactions in distance learning. The Turkish Online Journal of Educational Technology (TOJET), 4(1), 1303-6521. Retrieved from http://www.tojet.net/articles/v4i1/ 417.pdf

Thakur, P., \& Dutt, S. (2017). Problem based learning in biology: Its effect on achievement motivation of students of 9 th standard. International Journal of Multidisciplinary Education and Research, 2(2), 99104. Retrieved from http://www.educationjournal.in/download/186/2-2-53-447.pdf

Tîrziu, A.-M., \& Vrabie, C. (2015). Education 2.0: E-learning methods. In Procedia - Social and Behavioral Sciences (Vol. 186, pp. 376-380). doi: https://doi.org/10.1016/j.sbspro.2015.04.213

Triyanto, S. A., Susilo, H., \& Rohman, F. (2016). Penerapan blended-problem based learning dalam pembelajaran biologi. Jurnal Pendidikan: Teori, Penelitian Dan Pengembangan, 1(7), 1252-1260. doi: https://doi.org/10.17977/jp.v1i7.6526

Valverde-Berrocoso, J., Garrido-Arroyo, M. del C., Burgos-Videla, C., \& Morales-Cevallos, M. B. (2020). Trends in educational research about e-Learning: A systematic literature review (2009-2018). Sustainability (Switzerland), 12(12), 1-23. doi: https://doi.org/10.3390/su12125153

Walker, A., \& Leary, H. (2009). A problem based learning meta analysis: differences across problem types, implementation types, disciplines, and assessment levels. Interdisciplinary Journal of Problem-Based Learning, 3(1), 3-24. doi: https://doi.org/10.7771/1541-5015.1061

Wijnia, L. (2016). The problem with problems in problem-based learning: difference between problem explaining versus problem solving. Health Professions Education, 2(2), 59-60. doi: https://doi.org/10. 1016/j.hpe.2016.09.004

Yapici, I. Ü., \& Akbayin, H. (2012). The effect of blended learning model on high school students' biology achievement and on their attitudes towards the internet. Turkish Online Journal of Educational Technology, 11(2), 228-237. Retrieved from https://eric.ed.gov/?id=EJ989031

Yew, E. H. J., \& Goh, K. (2016). Problem-based learning: An overview of its process and impact on learning. Health Professions Education, 2(2), 75-79. doi: https://doi.org/10.1016/j.hpe.2016.01.004

Zabit, M. N. M. (2010). Problem-based learning on students critical thinking skills In teaching business education in Malaysia: A literature review. American Journal of Business Education (AJBE), 3(6), 19 32. doi: https://doi.org/10.19030/ajbe.v3i6.436

Zejnilagić-Hajić, M., Šabeta, A., \& Nuić, I. (2015). The effects of problem-based learning on students achievements in primary school chemistry. Bulletin of the Chemists and Technologists of Bosnia and Herzegovina, 44, 17-22. Retrieved from http://www.pmf.unsa.ba/hemija/glasnik/files/lssue 44/5-17-22Zejnilagi.pdf 